\title{
MAPPING AND CLASSIFICATION OF DIRECT EFFECTS OF THE FLOOD OF OCTOBER 2014 IN ATHENS
}

\author{
Diakakis M. ${ }^{1}$, Deligiannakis G. ${ }^{2}$, Katsetsiadou K. ${ }^{1}$, Lekkas E. ${ }^{1}$, Melaki M. ${ }^{1}$ \\ and Antoniadis Z. ${ }^{1}$ \\ ${ }^{1}$ National \& Kapodistrian University of Athens, Zografou, Athens, Greece, 302107274669, \\ diakakism@geol.uoa.gr \\ ${ }^{2}$ Agricultural University of Athens, Athens, Greece, gdeligian@aua.gr
}

\begin{abstract}
In 24 October 2014, a high intensity storm hit Athens' western suburbs causing extensive flash flooding phenomena. The drainage and the sewerage network of the city were overwhelmed leading to catastrophic flood flows along the road network, flooding houses and businesses, sweeping away vehicles, injuring people and causing numerous problems in transportation across the city. Parts of the city were inundated for several hours, particularly in western Athens, namely Ilion, Menidi, Peristeri, Acharnai, Korydallos and Piraeus. This work examines and reconstructs in detail the flood's characteristics, the different types of direct effects within the urban environment and the severity of its direct impacts across Athens basin. Results show a concentration of flood damages in specific locations mostly along the city's natural drainage network or derelict streams and culverts. At their peak stage, floodwaters extended to an area of 4.9 square $\mathrm{km}$ recording a maximum depth of $170 \mathrm{~cm}$ in certain locations. Eight types of direct impacts were identified in 1223 impact locations, including effects on vegetation, geomorphology, erosion, mobile objects, buildings, infrastructure and human population. A severity scale was developed allowing effects to be divided in five severity classes across the flooded area and making possible the delineation of high impact sections of the city.
\end{abstract}

Keywords: flash floods, effects, severity.

\section{Пєрí $\eta \psi \eta$}

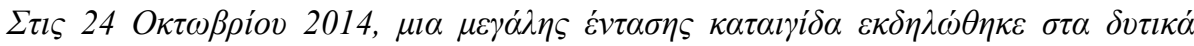

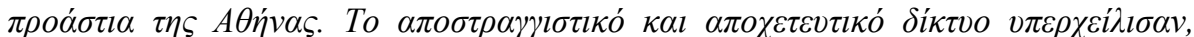

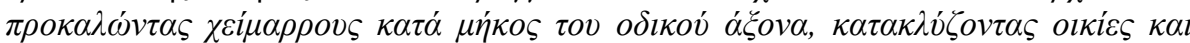

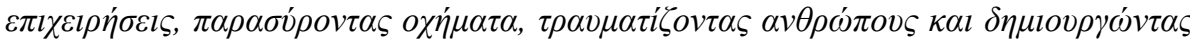

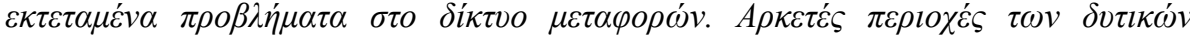

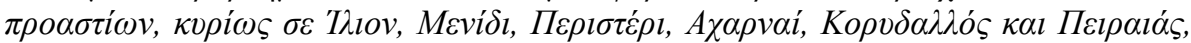

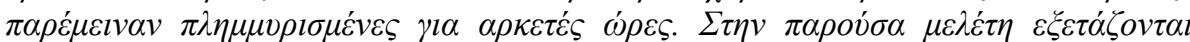

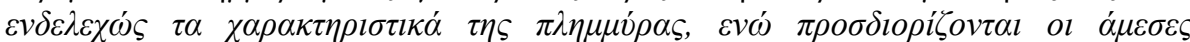

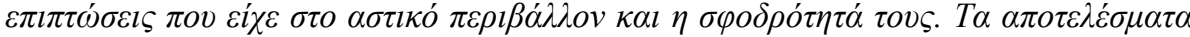

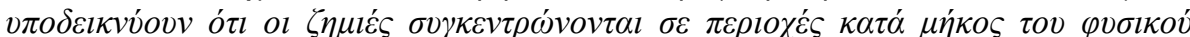

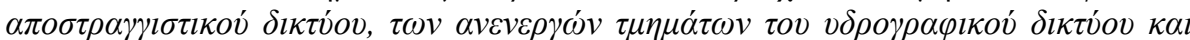

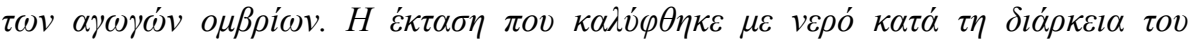

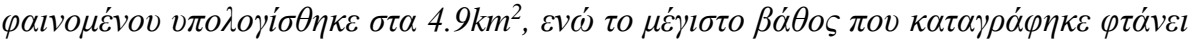

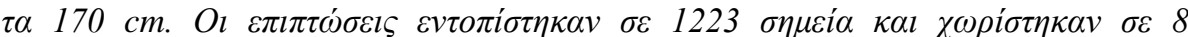




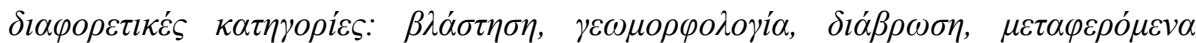

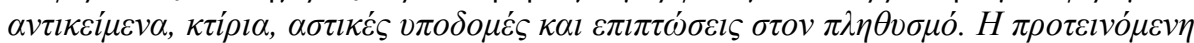

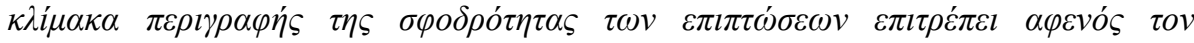

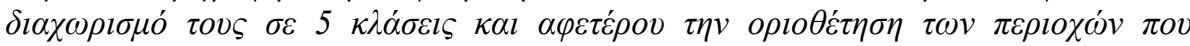
$\varepsilon \pi \lambda \dot{\eta} \gamma \eta \sigma \alpha \nu \pi \varepsilon \rho i \sigma \sigma o ́ \tau \varepsilon \rho o$.

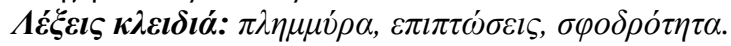

\section{Introduction}

Floods pose a significant threat to human life (Jonkman and Kelman, 2005) and cause extensive economic damages on a yearly basis (Barrero, 2007). Especially in urban environments, vulnerability is significantly increased as a higher concentration of population and assets makes flooding costly and difficult to manage. In addition, given the complexity of socio-economic activities in urban settlements, urban floods can potentially disrupt activities, businesses and social groups beyond the actual flooded area such as transportation services and others (Mitsakis et al., 2014). Due to this complexity, it is often particularly difficult to predict the impacts of floods in an urban environment and their severity. Moreover, the importance of urban floods in the overall risk is expected to grow even more (Jha et al., 2012) as global urban population is projected to increase further (Antrop, 2004; UN, 2011). Within the context of climate change, extreme storms like the one of October 2014, are expected to become more frequent (Alfieri et al., 2015) increasing the problem even further.

Previous works have examined the impact of floods (Petersen, 2001) categorizing the effects in various groups and severity levels (Calianno et al., 2013) such as: (a) impacts on human population (Jonkman and Kelman, 2005), (b) impacts on environment (Phillips, 2002), including agriculture (Chau et al., 2013), (c) impacts on transportation (Mitsakis et al., 2014) including vehicles and travel conditions and road infrastructure (Diakakis et al., 2016), (d) impacts on buildings (Smith, 1994; Fedeksi and Gwilliam, 2007) and on infrastructure (Diakakis et al., 2016).

To fully understand the impact of storm in a holistic way, it is important to identify and map the different types of effects in a highly detailed way. In this context, this study develops a method that provides a coherent overview of these effects through classification of their type and their severity level. In this way, the study aims to provide a detailed description of the flood of 2014 and its impacts.

\section{Study Area and the October 2014 Event}

Athens is the capital and the most extensive urban area in Greece. The city is situated in central Greece, in the region of Attica and is built in a morphologic basin that occupies an area of approximately 534 $\mathrm{km}^{2}$, formed between Penteli, Parnitha, Ymittos and Aigaleo mountains and Saronikos Gulf in the south (Fig. 1). The basin is shaped primarily by Kifissos and Ilissos river networks and is relatively dry with a mean annual rainfall of approximately $390 \mathrm{~mm}$ and a poorly developed river network dominated by streams with small amounts of water for most of the year (Koutsoyiannis and Baloutsos, 2000). The increased pressure for development has led to the expansion of human activities and infrastructure within the vicinity of Athens' ephemeral watercourses, in many cases in areas of elevated flood hazard, not suitable for building. Several authors suggest that poorly-planned development in the city has affected the drainage capacity of the river network noting that several parts of it were shrunk or converted into streets while critical river cross sections were diminished. In fact, Diakakis (2014) suggests that floods have increased in Athens basin during the last century, and even though immediate loss of life is not showing clear increase, fatalities still remain an issue.

On Friday the $24^{\text {th }}, 2014$, a deep barometric low, which formed over the Adriatic Sea, moved through the Ionian Sea, towards Peloponnese and subsequently Attica. Simultaneously with its passing over Athens, the system matured developing a line of storms feeding from the gulf of Saronikos, just south of Athens, leading to accumulation of rain up to $130 \mathrm{~mm}$ in 5 hours in the west part of Athens (Fig.1). 


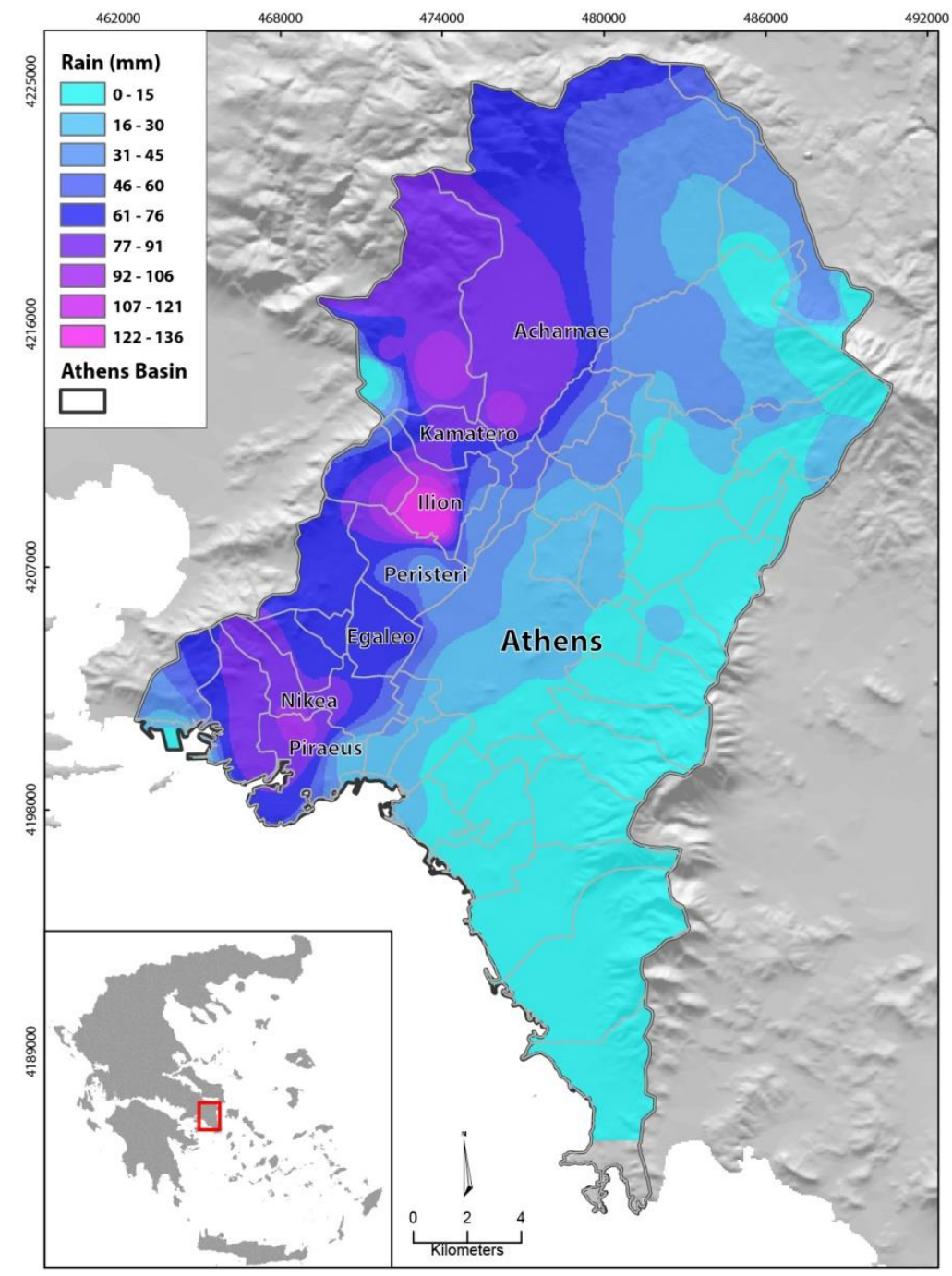

Figure 1 - Map of the rainfall distribution across Athens basin on the 24 October flood.

\section{Methodology}

Data on the effects of the October 2014 flood were collected from a variety of sources (Table 1) including official damage reports, visual material (pictures and video) and information gathered through post-flood field surveys. Data contained information on the exact location of damages, including detailed descriptions of the damage type and extent, the depth of floodwaters and in many cases visual material of the incident. After the collection of data, a geo-database was developed to store all information. Each entry of the database corresponded to one damage location, which was plotted on the map of the study area in a GIS environment. GIS algorithms were used then to:

- define the extent of flooding based on all recorded flooded locations

- reconstruct the depth of floodwaters using extrapolation of known flow depth

- define spatial distribution of damages and examine possible patterns in it

- define the spatial distribution of different types and different levels of damages to understand the severity of flooding in different locations 
Table 1 - Sources of information on 2014 floods effects and damages.

\begin{tabular}{|l|l|l|}
\hline Type of source & \multicolumn{1}{|c|}{ Source } & \multicolumn{1}{|c|}{\begin{tabular}{c}
\multicolumn{1}{|c|}{ Form of data } \\
(short description)
\end{tabular}} \\
\hline $\begin{array}{l}\text { Central } \\
\text { Government } \\
\text { Records }\end{array}$ & $\begin{array}{l}\text { Division of Natural Disaster Damages } \\
\text { Restoration, Ministry of Infrastructure, } \\
\text { Transport and Networks }\end{array}$ & $\begin{array}{l}\text { Database of household damages } \\
\text { recorded on Fire Service detailed } \\
\text { reports, including information on } \\
\text { address, type of damage, water } \\
\text { level. }\end{array}$ \\
\hline $\begin{array}{l}\text { Local } \\
\text { Government } \\
\text { Records }\end{array}$ & $\begin{array}{l}\text { Affected Municipalities, namely: Acharnes. } \\
\text { Agia Varvara, Agioi Anargiroi, Aigaleo, Fili, } \\
\text { Haidari, Ilion, Keratsini-Drapetsona, } \\
\text { Korydallos, Nikaia Peristeri, Piraeus }\end{array}$ & $\begin{array}{l}\text { Official resolution documents } \\
\text { regarding amends for residents, } \\
\text { whose household has been recorded } \\
\text { by the Fire Service as affected by the } \\
\text { October 24th flood. }\end{array}$ \\
\hline Media & $\begin{array}{l}\text { The nationwide TV stations Alpha TV, } \\
\text { Antenna TV, Mega TV, NERIT, SKAI TV and } \\
\text { STAR TV }\end{array}$ & $\begin{array}{l}\text { Video footage broadcasted between } \\
\text { 24/10 and 30/10/2014 on news } \\
\text { bulletin. Total duration: 16hours 16 } \\
\text { minutes 08 seconds. }\end{array}$ \\
\hline Web & $\begin{array}{l}\text { News portals, Video web platforms, Blogs, } \\
\text { Social media }\end{array}$ & $\begin{array}{l}\text { Video \& photos, recorded during } \\
\text { or just after the rainfall. }\end{array}$ \\
\hline $\begin{array}{l}\text { Post-flood } \\
\text { Field Survey }\end{array}$ & Survey & $\begin{array}{l}\text { Post flood field survey material, } \\
\text { including pictures, videos, depth } \\
\text { measurements and field notes. }\end{array}$ \\
\hline
\end{tabular}

The impact types were divided in groups (Tables 2 and 3), based on related literature classifications combined with observations carried out in the course of this study. In addition to the type of impact, in this work effects were also grouped according to their severity. The organization of different categories of severity is illustrated in the following table according to the type of impact (Tables 2 and 3).

Table 2 - Severity classes of effects on natural environment and population.

\begin{tabular}{|c|c|c|c|c|}
\hline \multirow[b]{2}{*}{$\begin{array}{l}\text { Severity } \\
\text { class }\end{array}$} & \multirow[b]{2}{*}{$\begin{array}{c}\text { Effects on } \\
\text { population }\end{array}$} & \multicolumn{3}{|c|}{ Effects on the natural environment } \\
\hline & & $\begin{array}{l}\text { Vegetation / } \\
\text { agriculture / } \\
\text { livestock }\end{array}$ & Pollution & $\begin{array}{c}\text { Geomorphology and river } \\
\text { morphology }\end{array}$ \\
\hline $\begin{array}{l}\text { Minor } \\
\text { impacts }\end{array}$ & $\begin{array}{l}\text { Daily } \\
\text { commute / } \\
\text { every day } \\
\text { activities } \\
\text { affected }\end{array}$ & $\begin{array}{l}\text { Vegetation debris } \\
\text { (leaves and } \\
\text { branches) drifted } \\
\text { by water. Urban } \\
\text { agricultural plots } \\
\text { suffer minor } \\
\text { inundation. }\end{array}$ & $\begin{array}{l}\text { No observable } \\
\text { impacts }\end{array}$ & $\begin{array}{l}\text { Less than } 2 \mathrm{~m}^{3} \text { of earth material } \\
\text { eroded or deposited at locations } \\
\text { along or over the river banks }\end{array}$ \\
\hline $\begin{array}{l}\text { Weak } \\
\text { impacts }\end{array}$ & $\begin{array}{l}\text { House or } \\
\text { business } \\
\text { affected by } \\
\text { flood }\end{array}$ & $\begin{array}{l}\text { Low vegetation } \\
\text { (ground plants and } \\
\text { reeds) bent or } \\
\text { uprooted. Beehives } \\
\text { get transported or } \\
\text { flooded. }<1 \text { ha } \\
\text { cultivated land }\end{array}$ & $\begin{array}{l}\text { Household utensils } \\
\text { furniture or trash } \\
\text { spread in the } \\
\text { watercourse }\end{array}$ & $\begin{array}{l}\text { Erosion and deposition } \\
\text { phenomena along or over the } \\
\text { banks of the river }(<10 \mathrm{~m} \\
\text { width). No channel changes }\end{array}$ \\
\hline
\end{tabular}




\begin{tabular}{|c|c|c|c|c|}
\hline $\begin{array}{l}\text { Moderate } \\
\text { impacts }\end{array}$ & \begin{tabular}{|l} 
\\
Evacuation \\
needed / \\
Injuries / \\
Rescues / \\
Individuals \\
under risk, \\
emergency or \\
entrapment
\end{tabular} & $\begin{array}{l}\text { Small tree } \\
\text { branches break. } \\
\text { Bushes are } \\
\text { uprooted. Few } \\
(<10 \%) \text { small trees } \\
\text { uprooted. Urban } \\
\text { plantations suffer } \\
\text { damages. }<100 \\
\text { livestock animals } \\
\text { dead, <10ha } \\
\text { cultivated land } \\
\text { flooded }\end{array}$ & $\begin{array}{l}\text { Liquid pollutants } \\
\text { (e.g. H/C) spread } \\
\text { locally (e.g. gas } \\
\text { stations flooded). } \\
\text { Pollution not } \\
\text { traceable in } \\
\text { groundwater }\end{array}$ & $\begin{array}{l}\text { Changes in natural river } \\
\text { channels not more extensive } \\
\text { than the original width of the } \\
\text { channel at the respective } \\
\text { location. Changes in the river } \\
\text { mouth not more extensive than } \\
\text { the original width of the river at } \\
\text { this point. Continuous } \\
\text { deposition on the floodplain of } \\
\text { less than } 50 \mathrm{~cm} \text { thickness (area } \\
\text { covered }<1000 \mathrm{~m}^{2} \text { ) at locations. }\end{array}$ \\
\hline $\begin{array}{l}\text { Strong } \\
\text { impacts }\end{array}$ & $\begin{array}{l}\text { Fatalities 1-10 } \\
\text { locally }\end{array}$ & $\begin{array}{l}\text { Most small trees } \\
\text { uprooted. Few } \\
(<10 \%) \text { big trees } \\
\text { uprooted or bent. } \\
>100 \text { livestock or } \\
\text { wild animals dead }\end{array}$ & $\begin{array}{l}\text { Liquid and solid } \\
\text { pollutants spread in } \\
\text { the watercourse not } \\
\text { only locally. } \\
\text { Pollution traceable } \\
\text { at distance }<5 \mathrm{~km} . \\
\text { Pollution traceable } \\
\text { in groundwater or } \\
\text { surface water } \\
\text { bodies }\end{array}$ & $\begin{array}{l}\text { Natural river channel changes } \\
\text { more extensive than the width } \\
\text { of the original channel at the } \\
\text { respective location. Changes at } \\
\text { river mouth more extensive } \\
\text { than the width of the original } \\
\text { channel at this point. } \\
\text { Continuous deposition on the } \\
\text { floodplain of more than } 50 \mathrm{~cm} \\
\text { but less than } 3 \mathrm{~m} \text { with an area } \\
\text { covered of } 1000 \mathrm{~m}^{2}-5000 \mathrm{~m}^{2} \text { at } \\
\text { locations is recorded. Minor } \\
\text { landslides caused by erosion }\end{array}$ \\
\hline $\begin{array}{l}\text { Extreme } \\
\text { impacts }\end{array}$ & $\begin{array}{l}\text { Over } 10 \\
\text { fatalities } \\
\text { locally }\end{array}$ & $\begin{array}{l}\text { Most trees } \\
\text { uprooted }\end{array}$ & $\begin{array}{l}\text { Major pollution } \\
\text { episode. Major } \\
\text { source of liquid } \\
\text { pollutants spread in } \\
\text { surface water } \\
\text { bodies and } \\
\text { groundwater. Area } \\
\text { affected not easily } \\
\text { determinable }\end{array}$ & $\begin{array}{l}\text { Deposition of sediment more tha } \\
\text { n } 3.5 \mathrm{~m} \text { thick (approximately the } \\
\text { height of a floor ceiling of an av } \\
\text { erage building) at specific locati } \\
\text { ons or continuous deposition on } \\
\text { the floodplain or on agricultural } \\
\text { land (allotments etc.) of more th } \\
\text { an } 50 \mathrm{~cm} \text { (area covered over } 500 \\
0 \mathrm{~m}^{2} \text { ) Natural channel changes at } \\
\text { the river mouth or other locatio } \\
\text { ns become more extensive than } \\
4 \text { times the original width of the } \\
\text { channel at the respective locatio } \\
\text { n before the flood. Large Landsli } \\
\text { des are caused due to erosion }\end{array}$ \\
\hline
\end{tabular}

Table 3 - Severity classes of effects on built environment and mobile objects.

\begin{tabular}{|l|l|l|l|}
\hline \multirow{2}{*}{$\begin{array}{c}\text { Severity } \\
\text { class }\end{array}$} & \multicolumn{2}{|c|}{ Effects on built environment } & \multicolumn{1}{c|}{$\begin{array}{c}\text { Effects on mobile } \\
\text { objects }\end{array}$} \\
\cline { 2 - 4 } & $\begin{array}{l}\text { Buildings } \\
\text { Yard / Garden / Pilotis } \\
\text { suffer inundation. Minor } \\
\text { cracks occur on yard } \\
\text { walls and fences. Minor } \\
\text { damages by absorbed } \\
\text { mointure on walls } \\
\text { impaction and others }\end{array}$ & $\begin{array}{l}\text { Inundation of road or sidewalk } \\
\text { surface (<15cm). Low water } \\
\text { crossings are flooded }\end{array}$ & $\begin{array}{l}\text { Flower pots / Small trash bi } \\
\text { ns / Small (e.g. tables, chair } \\
\text { s) furniture and mobile obje } \\
\text { cts of similar or smaller siz } \\
\text { e get transported } \\
\text { by floodwaters. Drivers ret } \\
\text { ain command of vehicles }\end{array}$ \\
\hline
\end{tabular}




\begin{tabular}{|c|c|c|c|}
\hline $\begin{array}{l}\text { Weak } \\
\text { impacts }\end{array}$ & $\begin{array}{l}\text { Ground floors suffer } \\
\text { minor flooding } \\
\text { (usually <20cm) } \\
\text { causing minor } \\
\text { damages to household } \\
\text { furniture, utensils or } \\
\text { equipment. Damages } \\
\text { on walls, garage doors, } \\
\text { floor tiles. Yard walls } \\
\text { and fences suffer } \\
\text { significant damages. }\end{array}$ & $\begin{array}{l}\text { Transportation installations (traffic } \\
\text { lights, signs, etc.) suffer damages. } \\
\text { Road not passable by car. Structural } \\
\text { effects (asphalt scouring, minor } \\
\text { erosion phenomena) are recorded on } \\
\text { road surface. Terminal stations } \\
\text { experience flooding and are } \\
\text { inaccessible but do not suffer more } \\
\text { than minor damages. Culverts are } \\
\text { blocked. Fences are partly damaged } \\
\text { and anchored trash installations } \\
\text { moved. Manhole covers are displaced. }\end{array}$ & $\begin{array}{l}\text { Large trash bins get transpo } \\
\text { rted by floodwaters. Cars ar } \\
\text { e moved by floodwaters (at } \\
\text { a distance less than their le } \\
\text { ngth). Drivers cannot fully } \\
\text { control cars or motorbikes }\end{array}$ \\
\hline $\begin{array}{l}\text { Moderate } \\
\text { impacts }\end{array}$ & $\begin{array}{l}\text { Ground floors suffer } \\
\text { flooding (usually } \\
<180 \mathrm{~cm} \text { ) that causes } \\
\text { significant or complete } \\
\text { damage to household } \\
\text { utensils or equipment, } \\
\text { including wall and } \\
\text { flood tiles, door and } \\
\text { window frames. Slight } \\
\text { crevices appear in } \\
\text { supporting elements }\end{array}$ & $\begin{array}{l}\text { Roads suffer structural effects (partial } \\
\text { collapse of asphalt deck. Single span } \\
\text { bridges are flooded. Railway lines } \\
\text { become impassable due to inundation. } \\
\text { Terminal stations suffer flooding and } \\
\text { damages. Small footbridges suffer } \\
\text { partial collapse due to erosion of } \\
\text { foundations. Single span bridges } \\
\text { suffer inundation and minor damages } \\
\text { (e.g. guard rails or asphalt deck are } \\
\text { damaged). Concrete / artificial river } \\
\text { banks suffer damages. Power lines } \\
\text { (columns) and landlines are affected. }\end{array}$ & $\begin{array}{l}\text { Most cars / vans / minivans } \\
\text { / SUVs get transported at a } \\
\text { distance more than their } \\
\text { length. Drivers cannot } \\
\text { control cars or motorbikes } \\
\text { at all. Empty commercial } \\
\text { containers get transported } \\
\text { by floodwaters }\end{array}$ \\
\hline $\begin{array}{l}\text { Strong } \\
\text { impacts }\end{array}$ & $\begin{array}{l}\text { Complete damage of } \\
\text { household utensils or } \\
\text { equipment by flooding } \\
\text { (usually }>180 \mathrm{~cm} \text { ). } \\
\text { Major crevices or } \\
\text { holes, settlements, } \\
\text { deformations or partial } \\
\text { collapses appear in } \\
\text { supporting walls or } \\
\text { slabs. Replacement of } \\
\text { supporting elements } \\
\text { required. }\end{array}$ & $\begin{array}{l}\text { Single span bridges suffer partial } \\
\text { collapses to non-repairable damage } \\
\text { due to erosion of foundations. Parts } \\
\text { of the road suffer complete collapse } \\
\text { (asphalt deck and foundations are } \\
\text { damaged). Damages appear in port } \\
\text { infrastructure (docks / piers). Multi- } \\
\text { span bridges inundated (partial } \\
\text { damages may occur on deck and } \\
\text { railings). Water / sewage / gas } \\
\text { mains break. }\end{array}$ & $\begin{array}{l}\text { Most vehicles at a location } \\
\text { (including busses, small } \\
\text { tractors and smaller) get } \\
\text { transported by floodwaters. } \\
\text { Over } 30 \text { vehicles } \\
\text { transported. Laden } \\
\text { containers can be moved by } \\
\text { floodwaters }\end{array}$ \\
\hline $\begin{array}{l}\text { Extreme } \\
\text { impacts }\end{array}$ & $\begin{array}{l}\text { Significant damage } \\
\text { with structural collapse } \\
\text { of supporting walls, } \\
\text { slabs, leading to } \\
\text { collapse of the } \\
\text { building or of major } \\
\text { parts of the building. } \\
\text { Demolition of the } \\
\text { building is required. }\end{array}$ & $\begin{array}{l}\text { Single span and multi-span bridges } \\
\text { suffer partial or complete collapses } \\
\text { due to erosion of foundations. Large } \\
\text { armed concrete constructions suffer } \\
\text { partial but significant damage or } \\
\text { complete collapse. Small dams } \\
\text { break. }\end{array}$ & $\begin{array}{l}\text { Most vehicles (including } \\
\text { trucks and larger) and } \\
\text { larger objects get } \\
\text { transported or moved by } \\
\text { floodwaters. Drivers of all } \\
\text { vehicles do not have } \\
\text { control of them. }\end{array}$ \\
\hline
\end{tabular}

\section{Results}

In total, 1223 entries (damage locations) were stored in the database representing locations where the flood had an observable impact (Fig. 2). The effects spread in 16 municipalities covering a large part of the western part of the city, mostly following the rainfall accumulation distribution (Fig. 1). 
Comparison of flooded locations with the local streams shows that the majority of locations are within $200 \mathrm{~m}$ of an existing natural or artificial, derelict or active part of the local drainage network. However, a considerable amount of the locations are in parts of the city (especially near Menidi) with no torrents presence, showing that flooding at that location was caused by inadequacy of the urban drainage and was enhanced by the impermeable artificial surfaces.

Using the locations, visual material and information from the post-flood field survey it was possible to delineate the extent of the flood and to reconstruct the depth of floodwaters across the flooded area (Fig. 3). From this reconstruction it was found that floodwaters extended to an area of $4.9 \mathrm{~km}^{2}$, recording depths up to $170 \mathrm{~cm}$ in certain locations, on the west part of Piraeus port, Nikaia and the locations between Aigaleo and Peristeri (Figure 3, sections 1 and 2 of the map).

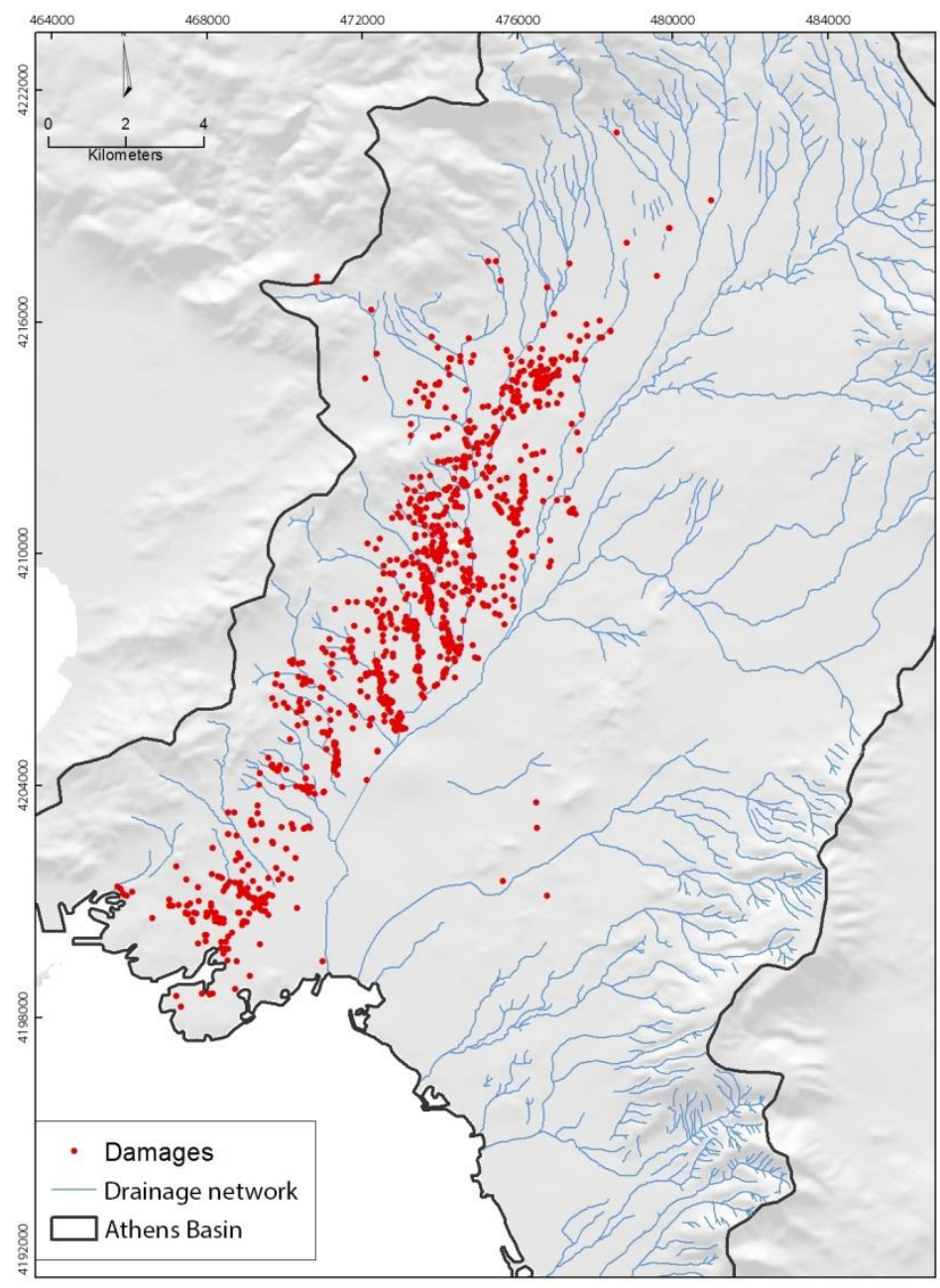

Figure 2 - Map of the study area depicting all recorded flood impact locations.

The types of effects were mapped individually, leading to the development of a concise map of different types of impacts. Five grades of severity of effects (minor, weak, moderate, strong and extreme) were included to identify possible patterns in damage level across the flooded area. The pattern created (Fig. 4) is providing a lot of information on the extent of effects in space and in severity and is expected to be useful for future risk evaluation studies. For instance additional locations susceptible to flooding (moderate impact) were identified in comparison with the risk maps 
developed for the same area by Diakakis et al. (2011). Additional locations were identified mostly at the border of Peristeri and Ilion municipalities.

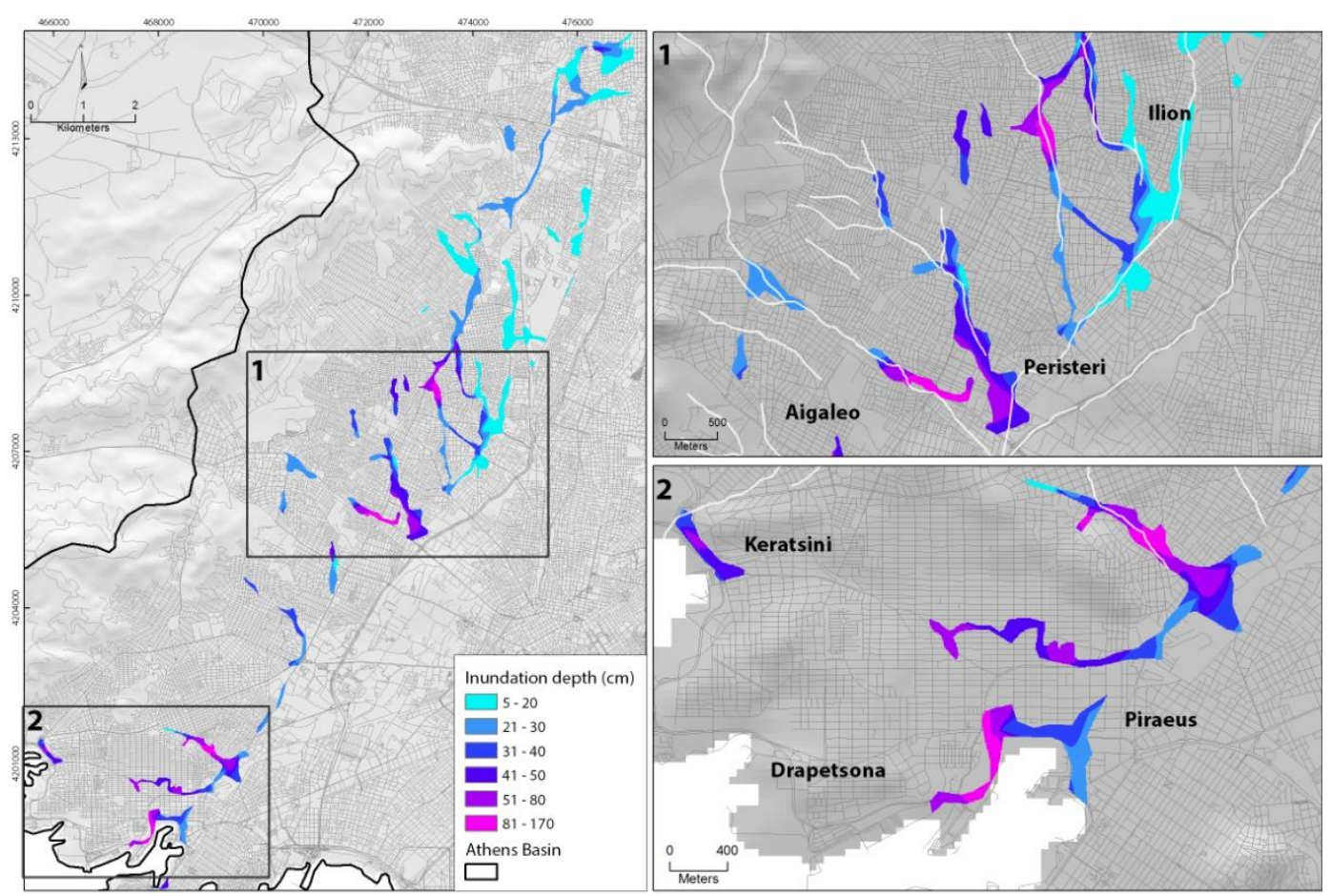

Figure 3 - Reconstruction of the extent and depth of floodwaters.

Based on the analysis of 1223 damage locations, results highlighted areas with concentrated effects of moderate and above-moderate impacts (dotted lines in Figure 4). In specific, a clustering of moderate (yellow) and strong impacts (orange) was recorded in locations at Menidi in the north, at Nikaia area near the port of Piraeus and finally at a higher concentration near the merging of Kifissos River with the Eschatia River tributary (Fig 4). Almost all effects in the latter location, concentrated upstream of the outlet of Eschatia to Kifissos proving that the drainage in this part of the basin is less efficient, probably due to diminished cross sections and the numerous structures built in the floodplain. The degree that these two factors affect the damage distribution is not clear as rainfall accumulation spatial spread is also an influencing parameter.

Areas with higher severity levels coincide partly with flood depth recorded in Figure 3. Areas with high numbers both in flood depth and impact can be found at the southern part of the study area at the Nikaia area (Figure 4 and section 2 in Figure 3) just north of Piraeus. In addition, at the southernmost border of section 1 in Figure 3 map between Aigaleo and Peristeri, where high depth values are recorded, severity of effects is also dominated by moderate to strong levels. 


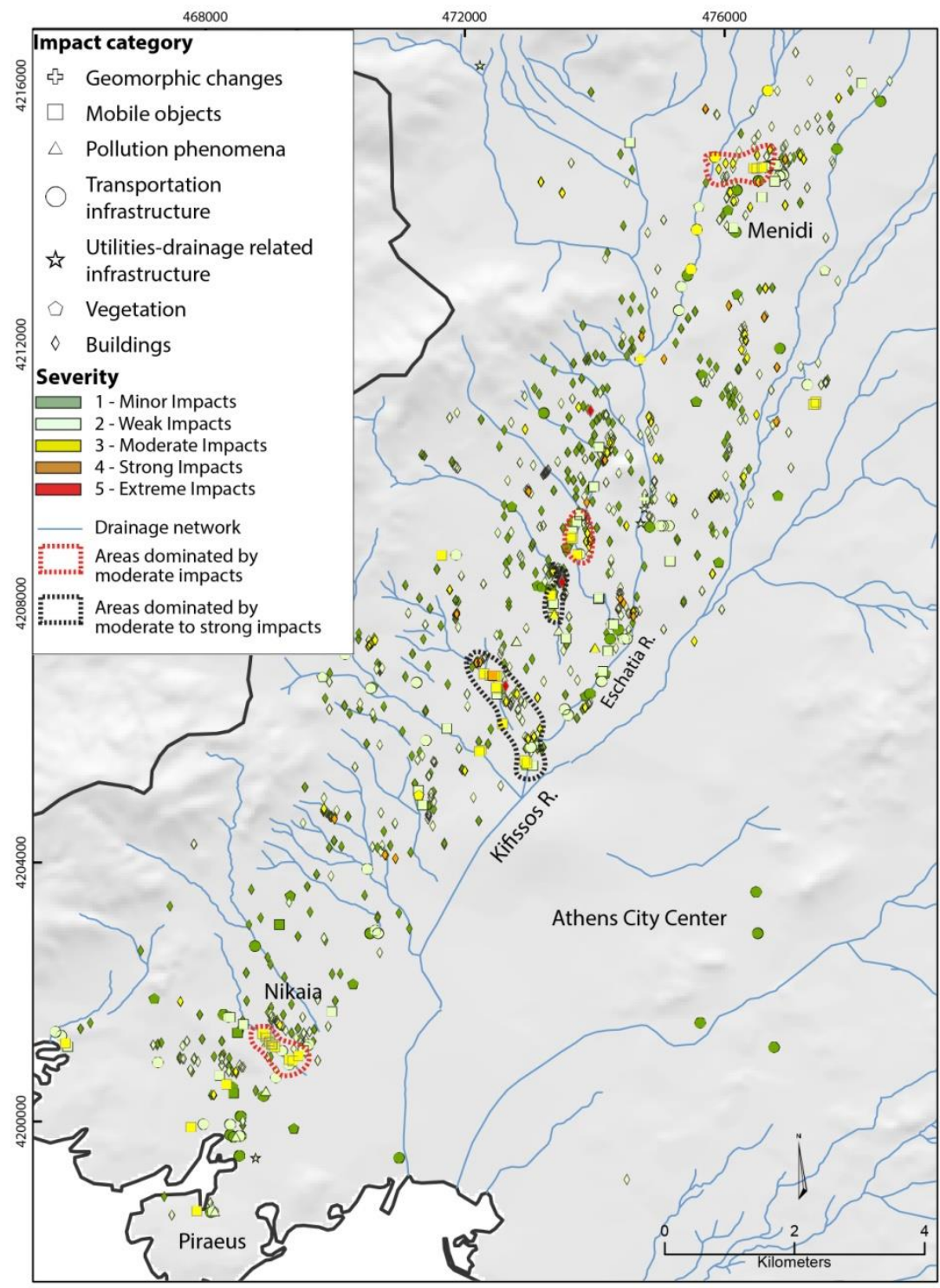

Figure 4 - Map of the study area depicting the severity classes at 1223 damage locations.

\section{Conclusions}

This work examines the effects of the flash flood of October 2014 in Athens basin in Greece and reconstructs floodwaters extent and depth. It records the different types of direct effects within the urban environment and the severity of its direct impacts across the flooded area. The study identifies 1223 damage locations spread across 16 municipalities of Athens basin, including damages on buildings, vegetation, geomorphology, humans, mobile objects, transportation and other infrastructure elements. Results show a concentration of flood damages in specific locations mostly near the city's natural drainage network, parts of which have been converted to culverts or streets and were derelict for decades. Floodwaters were found to extend to an area of 4.9 square $\mathrm{km}$ recording a depth up to $170 \mathrm{~cm}$ in certain locations. Direct impacts were grouped in 5 classes of 
severity, with most important effects clustering in particular locations within Nikaia, Aigaleo, Peristeri, Ilion and Menidi. The method was found to produce satisfying results in impact mapping and classification, and its diverse elements provide a possibility to be test in different environments (both rural and urban). Based on this study's findings, future research and practice should improve local risk assessment maps by adding additional locations recorded as susceptible to flooding, should highlight the areas that present more significant impact levels for civil protection initiatives and examine the applicability of a flood severity scale in other environments as a tool to map, in order to classify and understand flood effects more efficiently.

\section{References}

Alfieri, L., Burek, P., Feyen, L. and Forzieri, G., 2015. Global warming increases the frequency of river floods in Europe, Hydrol. Earth Syst. Sci. Discuss., 12, 1119-1152.

Antrop, M., 2004. Landscape change and the urbanization process in Europe, Landsc. Urban Plan., $67,9-26$.

Barredo, J.I., 2007. Major flood disasters in Europe: 1950-2005, Nat. Hazards, 42, 125-148.

Caliano, M., Ruin, I. and Gourley, J., 2013. Supplementing flash flood reports with impact classifications, Journal of Hydrologie, 477, 1-16.

Chau, V.N., Holland, J., Cassells, S. and Tuohy, M., 2013. Using GIS to map impacts upon agriculture from extreme floods in Vietnam, Applied Geography, 41, 65-74.

Diakakis, M., Foumelis, M., Gouliotis, L. and Lekkas, E., 2011. Preliminary flood hazard and risk assessment in Western Athens Metropolitan area, In: Lambrakis, N., Stournaras, G. and Katsanou, K., eds., Advances in the Research of Aquatic Environment, 1, 147-154, Springer.

Diakakis, M., 2014. An inventory of flood events in Athens, Greece, during the last 130 years. Seasonality and spatial distribution, Journal of Flood Risk Management, Wiley, DOI: 10.1111/jfr3.12053.

Diakakis, M., Lekkas, E., Stamos, I. and Mitsakis, E., 2016. Vulnerability of transport infrastructure in Greece to high intensity rainstorms in small rural catchments, European Journal of Transport and Infrastructure Research, Special Issue 'Climate Adaptation and Infrastructure' (accepted for publication).

Fedeksi, M. and Gwilliam, J., 2007. Urban sustainability in the presence of flood and geological hazards: The development of a GIS-based vulnerability and risk assessment methodology, Landscape and Urban Planning, 83, 50-61.

Jha, A.K., Block, R. and Lamond, J., 2012. Cities and Flooding, In A Guide to Integrated Urban Flood Risk Management for the 21st Century; The World Bank: Washington, DC, USA, 2012, 14-49.

Jonkman, S.N. and Kelman, I., 2005. An analysis of the causes and circumstances of flood disaster deaths, Disasters, 29(1), 75-97.

Koutsogiannis, D and Baloutsos, G., 2000. Analysis of a long record of annual maximum rainfall in Athens, Greece, and design rainfall inferences, Nat. Hazards, 22, 29-48.

Mitsakis, E., Stamos, I., Diakakis, M. and Grau, J.S. 2014. Impacts of high intensity storms on urban transportation: Applying traffic low control methodologies for quantifying the effects, International Journal of Environmental Science and Technology, doi: 10.1007/s13762-014-0573-4.

Petersen, M.S., 1999. Impacts of flash flood. In: Gruntfest, E. and Handmer, J. eds., Coping with flash flood, Nato Science Series, Environmental Securities, 77(J.), 11-13.

Phillips, J., 2002. Geomorphic impacts of flash flooding in a forested headwater basin, Journal of Hydrology, 269, 236-250.

Smith, D.I., 1994. Flood damage estimation - A review of urban stage damage curves and loss functions, Australian National Univerisity, Canberra 0200, Australia.

United Nations, 2011. World Urbanization Prospects; United Nations, Department of Economic and Social Affairs (DESA), Population Division, Population Estimates and Projections Section: New York, NY, USA, 2011. 